\title{
Appearances of the stools after the introduction of blood into the caecum
}

\author{
R. G. LUKE, W. LEES, AND J. RUDICK \\ From Glasgow Royal Infirmary
}

EDITORIAL SYNOPSIS These experimental observations on patients in whom blood was introduced into the caecum at appendicectomy suggest that the rate of passage of the blood rather than the level of its insertion determines the colour of the stool.

In Great Britain a melaena stool is usually defined as a black, tarry stool. The appearance is thought to be due to haematin and perhaps other pigments resulting from the breakdown of haemoglobin (Harrison, 1957). It is usually considered to indicate bleeding from the upper alimentary tract (Abrahams, 1954) although melaena has been observed in bleeding from a carcinoma of the caecum (Avery Jones and Gummer, 1960).

Schiff, Stevens, Shapiro, and Goodman (1942) introduced blood into the stomachs of patients by tube and found that 100 to $200 \mathrm{ml}$. of blood was required to give a tarry stool and, after $1,000 \mathrm{ml}$., red blood could be passed in four hours and a tarry stool in 20 hours. Hilsman (1950) using a Miller-Abbott tube inserted $200 \mathrm{ml}$. of blood to varying levels of the small gut and observed the differences which occurred when the transit time of the blood was altered by the action of drugs. Their main conclusion was that the rate of passage of the blood rather than the level of its insertion determined the colour of the stool. They also inserted $200 \mathrm{ml}$. of blood at varying levels of the colon in six cases and suggested from these studies that a melaena stool was formed proximal to the ascending colon.

We were interested in whether a melaena stool or red blood could be produced experimentally by introducing blood into the caecum and in the factors determining the subsequent appearance of the stool.

\section{MATERIAL AND METHODS}

The blood was usually expired bank blood except in the case of smaller volumes when the patient's own blood was sometimes used. The blood was always seen to be red and was introduced into the caecum at appendicectomy for acute or chronic appendicitis. The appendix was mobilized and delivered into the wound, and subtotal appendicectomy performed, leaving about a $\frac{3}{4}$ in. stump. Blood was introduced into the caecum through a drip set or syringe attached to a Guest cannula inserted into the appendix stump. Even with the larger volumes the caecum was never distended. The appendix stump was excised and the operation completed as for routine appendicectomy. Volumes of blood introduced into the caecum of an individual patient varied between 25 and $400 \mathrm{ml}$. In some cases a solution of $1 \mathrm{~g}$. of neomycin sulphate in sterile water was run in with the blood to study the effect of inhibiting bacterial action. The first two stools passed after operation were inspected by one of us, and if no red blood was seen the stool was tested by Occultest tablets in the routine way. Stools from 10 patients not given blood at appendicectomy were also studied as controls. Ether and water extracts from some of the stools not containing red blood were examined in a Hartridge spectroscope for haemoglobin, oxyhaemoglobin, and haematin pigments by the method described by Harrison (1957). There was no increase in postoperative morbidity in the patients studied.

\section{RESULTS}

It will be seen (Table I) that a melaena stool is passed only after $300 \mathrm{ml}$. or more of blood (in $56 \%$ of cases) and red blood after $200 \mathrm{ml}$. or more (21\% of cases). Fifty per cent of the melaena stools were loose and $50 \%$ formed. When $100 \mathrm{ml}$. or more of blood was given one or more dark stools were passed.

Times, with ranges, from the insertion of the blood into the caecum until the passage of the stools, are shown in Table II. There is a significant difference in the average time between groups 5 and 6,72 and 24 hours respectively (applying the $t$ test, $P<0.001$ ). Red blood was seen at later times after neomycin than when blood was inserted alone but the groups are too small to justify statistical analysis.

Two out of three patients given $400 \mathrm{ml}$. of blood 
TABLE I

CORRELATION BETWEEN AMOUNTS OF BLOOD AND STOOL APPEARANCES

\begin{tabular}{|c|c|c|c|c|c|}
\hline Amount of Blood Inserted $(\mathrm{ml})$. & No. of Cases & No. with Red Blood & Colour & \multicolumn{2}{|c|}{ Comment } \\
\hline 400 & 19 & 5 & 10 melaena, rest dark & 1 & $\begin{array}{l}\text { Fourteen melaena (both stools in seven } \\
\text { cases, second only in four cases) }\end{array}$ \\
\hline 350 & 3 & - & 2 melaena, rest dark & 2 & $\begin{array}{l}\text { Seven red blood (both stools in two } \\
\text { cases, and always in first stool) }\end{array}$ \\
\hline 300 & 3 & - & 2 melaena, rest dark & & \\
\hline 250 & 3 & 1 & & & \\
\hline 200 & 6 & 1 & No melaena but & & \\
\hline 150 & 1 & - & $\begin{array}{l}\text { one stool always } \\
\text { dark }\end{array}$ & & \\
\hline 100 & 5 & - & $\int$ dark & & \\
\hline 50 & 4 & - & 2 dark, rest normal & & \\
\hline 25 & 5 & - & 1 dark, rest normal & & \\
\hline $400+$ Neomycin & 9 & 5 & Red-brown & & $\begin{array}{l}\text { ve red blood (after neomycin) (both stools } \\
\text { three cases, and always in first stool) }\end{array}$ \\
\hline None (controls) & 10 & - & Normal & & $\begin{array}{l}\text { sts for occult blood all negative except } \\
\text { e positive in } 70 \text { seconds }\end{array}$ \\
\hline
\end{tabular}

TABLE II

TIMES FROM OPERATION TILL STOOL PASSED

\begin{tabular}{|c|c|c|c|c|}
\hline \multicolumn{2}{|c|}{ Group } & No. of & $\begin{array}{l}\text { Average Time to First } \\
\text { Stool (hours) }\end{array}$ & $\begin{array}{l}\text { Range } \\
\text { (hours) }\end{array}$ \\
\hline 1 & Control & 10 & 65 & $31-104$ \\
\hline 2 & Blood alone $(25-400 \mathrm{ml})$. & 49 & 66 & 4-108 \\
\hline 3 & Blood alone $(400 \mathrm{ml})$. & 19 & 60 & 4-94 \\
\hline 4 & Blood (400 ml.) + & & & \\
\hline & neomycin & 9 & 44 & $30-70$ \\
\hline 5 & Melaena $^{1}$ & 14 & 72 & $30-94$ \\
\hline 6 & Red blood 1 & 7 & 24 & 4-36 \\
\hline 7 & Red blood/neomycin & 5 & 41 & $30-56$ \\
\hline
\end{tabular}

'One sase of red blood and melaena at 30 hours

with $1 \mathrm{~g}$. of neomycin had melaena but in nine further patients in whom local neomycin was combined with an oral dosage of $1 \mathrm{~g}$. six hourly for the first 48 hours after operation, no melaena stools were seen (Table I).

The results of spectroscopy are shown in Table III.

TABLE III

RESULTS OF SPECTROSCOPY

\begin{tabular}{|c|c|c|}
\hline \multicolumn{2}{|c|}{ Group } & \multirow{2}{*}{$\begin{array}{l}\text { Results } \\
\begin{array}{l}\text { Eight haemoglobin }+ \text { haematin } \\
\text { One haemoglobin }\end{array}\end{array}$} \\
\hline 1 & Nine cases melaena & \\
\hline 2 & $\begin{array}{l}\text { One } 400 \mathrm{ml} \\
, \quad 250 \mathrm{ml} . \\
, \quad 200 \mathrm{ml} . \\
" 100 \mathrm{ml} . \\
\text { (no melaena) }\end{array}$ & $\begin{array}{l}\text { Haemoglobin + haematin } \\
\text { Haemoglobin + haematin } \\
\text { Haemoglobin + haematin } \\
\text { Haemoglobin }\end{array}$ \\
\hline 3 & $\begin{array}{l}\text { Four cases } 400 \mathrm{ml} .+ \\
\text { neomycin (no melaena) }\end{array}$ & All oxyhaemoglobin only \\
\hline
\end{tabular}

Values (to the nearest five seconds) of the more strongly positive Occultest result for each case studied are plotted (Fig. 1) against the amount of blood introduced. The result was less than 60 seconds for at least one of the stools in all patients given blood. There was a fair correlation between the Occultest results and the amount of blood inserted. 
group. Where spontaneous caecal bleeding occurs, however, the transit time for the blood might well be less as the colon would not be subjected to surgical trauma and to an anaesthetic. In practice when there is bleeding from the caecum a melaena stool is seldom observed, presumably because of the time and the relatively large volume of blood required to produce it.

We are grateful to Mr. A. A. Bonar, Mr. W. Beattie, Mr. W. Patrick, and Mr. C. J. Longland for allowing us to study patients in their wards.

Our thanks are also due to Professor E. M. McGirr for criticism and advice.
We are indebted to Dr. G. W. McNicol, of the Department of Biochemistry, Glasgow Royal Infirmary, who carried out the spectroscopic examinations.

\section{REFERENCES}

Abrahams, A. (1954). In Melaenci. French's Index of Differential Diagnosis, 7th ed., edited by A. H. Douthwaite, pp. 468-469. Wright, Bristol.

Avery Jones, F., and Gummer, J. W. P. (1960). Clinical Gastroenterology, p. 288. Blackwell, Oxford.

Harrison, G. A. (1957). Chemical Methods in Clinical Medicine, pp. 513 and 516. Churchill, London.

Hilsman, J. H. (1950). The color of blood-containing feces following the instillation of citrated blood at various levels of the small intestine. Gastroenterology, 15, 131-134.

Schiff, L., Stevens, R. J., Shapiro, N., and Goodman, S. (1942) Observations on the oral administration of citrated blood in. man. Amer. J. med. Sci., 203, 409-412. 